\begin{tabular}{|c|c|c|}
\hline \multirow{3}{*}{$\begin{array}{l}\text { BENTHAM OPEN } \\
\text { CrossMark }\end{array}$} & $\begin{array}{c}\text { The Open Cybernetics \& Systemics } \\
\text { Journal }\end{array}$ & $\begin{array}{l}\text { The Open } \\
\text { cyberectic \& Systemics } \\
\text { lournal }\end{array}$ \\
\hline & Content list available at: www.benthamopen.com/TOCSJ/ & 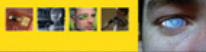 \\
\hline & $: 10.2174 / 1874$ & \\
\hline
\end{tabular}

\title{
RETRACTION
}

\section{Retraction Notice: The WSN Energy Efficient Protocol Based on Adaptive Mechanism of Sleep}

Liu Changzheng and Zhang Ronghua*

College of Information Science and Technology, Shihezi University, Shihezi, 832003, China

\section{RETRACTION}

The Publisher and Editor have retracted this article [1] in accordance with good ethical practices. After thorough investigations we believe that the peer review process was compromised. The article was published online on 29-05-2015.

\section{REFERENCE}

[1] L. Changzheng, and Z. Ronghua, "The WSN energy efficient protocol based on adaptive mechanism of sleep", Open Cybern. Syst. J., vol. 9, pp. 478-482, 2015.

* Address correspondence to this author at the College of Information Science and Technology, Shihezi University, Shihezi, 832003, China; Tel: +86 993 2058090; E-mail: zrh_oea@sina.com 